\section{Francuskie (nie)oswajalne widmo. Wielka Wojna w małych formach narracyjnych}

Piotr Sadkowski

TEKSTY DRUGIE 2018, NR 4, S. 94-114

DOI: $10.18318 /$ td.2018.4.6
Niniejszy artykuł powstał

w ramach pracy nad projektem Trauma kulturowal wojnyświatowej we współczesnej literaturze brytyjskiej, francuskieji kanadyjskiej finansowanym ze środków Narodowego Centrum Nauki DEC$-2013 / 11 / \mathrm{B} / \mathrm{HS} 2 / 02871$.
1.

Figura widma w narracjach o francuskich traumach historycznych uwypukla syndrom poczucia winy i konfliktu między pragnieniem zapomnienia a potrzebą postpamięciowej rekonstrukcji lub symbolicznej substytucji świadectw cierpienia. W tomie L'imaginaire spectral de la littérature narrative française contemporaine, wydanym w roku 2012, Claude Burgelin opisuje literaturę jako przestrzeń, gdzie brzmią głosy, albo raczej daje się słyszeć cisza, stłumiona skarga powracających, po upływie jednego lub dwóch pokoleń, duchów ofiar wojen. Tym samym pisarstwo metaforyzuje nagrobek w jego podwójnej funkcji polegającej zarówno na chowaniu zmarłych, jak $\mathrm{i}$ ich upamiętnianiu, czy symbolicznym utrwalaniu istnienia'. Collin Netellbeck, odnosząc się do spektralnych

1 Zob. C. Burgelin Esquisse d'une fantomologie, w: L'imaginaire spectral de la littérature narrative française contemporaine, dir. J. Fortin, J.-B. Vray, Publications de I'Université de Saint-Étienne, Saint-Étienne 2012, s. 227-236.
Piotr Sadkowski - dr hab., adiunkt w Katedrze Filologii Romańskiej Uniwersytetu Mikołaja Kopernika wToruniu. Prowadzi badania dotyczące frankofońskiego pisarstwa migracyjnego, mitu w literaturze, postpamięci. Autor monografii Récits odysséens. Le thème du retour d'exil dans lécriture migrante au Québec et en France (2011). Kontakt: Piotr. Sadkowski@umk.pl 
obrazów II wojny u Patricka Modiano, zwraca uwagę, że pod jedną traumą zbiorową mogą kryć się inne traumy oraz wyparte lub wyidealizowane doświadczenia związane z Wielką Wojną ${ }^{2}$. Podobnie Dominique Viart podkreśla znaczenie kontestacji - poprzez alternatywne, „widmowe” strategie opowiadania o traumatycznej przeszłości - oficjalnych narracji o Historii. Literatura współczesna uwidacznia więc rozdarcie między świadomością niemożności zastąpienia świadków a koniecznością wyrażania niewyrażalnego widma nawiedzającego teraźniejszośćs. Stéphane Chaudier, ze swej strony, określa zjawy przeszłości jako „naszych „wierzycieli”, „sędziów”, pełniących rolę „superego", traktowanych jako tym bardziej silnych i władnych, im bardziej ich postać jawi się ulotna i krucha ${ }^{4}$.

W tekstach literackich, których dotyczą przywołane powyżej ujęcia teoretyczne i krytyczne, spektralność odnosi się najczęściej do traumy zapośredniczonej po II wojnie. Spotkanie ze zjawami jest tu doświadczeniem niezbędnym, by uruchomić proces żałoby. Prowadzi także do uświadomienia stanu osierocenia tożsamości narracyjnej podmiotu podejmującego wysiłek scalenia rozproszonych śladów przeszłości mimo luk w pamięci międzypokoleniowej spowodowanych przez niszczycielskie działanie wielkiej Historii ${ }^{5}$.

W 2005 roku Dominique Viart, opisując przemiany zachodzące w prozie francuskiej od końca lat 80 . ubiegłego stulecia, zwracał uwagę na gwałtowny wzrost zainteresowania I wojną. Po nieobecności w literaturze w ciągu dwóch poprzednich dekad Wielka Wojna stała się we Francji najczęściej podejmowanym tematem w powieściach ilustrujących powrót do koncepcji prozy jako opowieści o człowieku i jego zmaganiach z Historią ${ }^{6}$. Co istotne, autorzy piszący w tym okresie o katastrofie 1914 roku należą do pierwszego pokolenia

2 Zob. C. Nettelbeck Le grand désarroi des (sur)vivants: la spectralité dans l'imaginaire narrationnel de la France contemporaine, w: L'imaginaire spectral..., s. 25-31.

3 Zob. D. Viart Vers une poétique „spectrale” de l'Histoire, w: tamże, s. 37-51.

4 Zob. S. Chaudier Petite enquête sur le désir contemporain de spectralité, w: tamże, s. 210-211.

5 Odnoszę się tu do koncepcji Paula Ricœura traktującego tożsamość narracyjną jednocześnie w kategoriach jednostkowych i wspólnotowych. „Możemy mówić o byciu sobą wspólnoty, tak jak mówimy o byciu sobą pojedynczego podmiotu: jednostka i wspólnota konstytuują się w swojej tożsamości, przejmując określone opowieści, które stają się zarówno dla jednej, jak drugiej ich historią rzeczywistą". P. Ricœur Czas i opowieść. Tom 3. Czas opowiadany, przeł. U. Zbrzeźniak, Wydawnictwo UJ, Kraków 2008, s. 353.

6 Zob. D. Viart La littérature contemporaine et la Grande Guerre, w: D. Viart, B. Vercier La littérature française au présent. Héritage, modernité, mutations, Bordas, Paris 2005, s. 127-130. 
Francuzów urodzonych w XX wieku, którzy bezpośrednio nie doświadczyli żadnej z dwóch wojen światowych. Są oni natomiast świadkami umierania ostatnich uczestników I wojny, których przeżycia były prawie albo całkowicie nieznane ich potomkom, gdyż „zostały wykreślone ze wspomnień rodzinnych w okresie 1950-1980"7. Dlatego też nowe narracje o Wielkiej Wojnie obrazują, jak to określa Carine Trevisan, wysiłek potomka usiłującego wyobrazić sobie cierpienia przodków. Pisarze starają się wydobyć na światło dzienne historie "nie tyle zapomniane, co zablokowane” i przedstawić się jako „problematycznych spadkobierców" przemilczanego bólu ${ }^{8}$. Stąd też werbalizacja traumy za pośrednictwem tekstu literackiego pozwala, według Trevisan, współczesnym powieściopisarzom poddać analizie, to co z Wielkiej Wojny zostało im przekazane nieświadomie:

Praca opowieści ma na celu nazwanie duchów, które kolonizują ",ja”, aby móc się uwolnić od często niszczącego wpływu [...]. U schyłku wieku, pod postacią mrocznych obrazów, dziwnych i przestarzałych opowiadań, Wielka Wojna jawi się w niepokojącej i fascynującej aurze, jako wydarzenie wystarczająco bliskie, by nas osobiście dotykać, wystarczająco dalekie, by stawać się niejasnym mitem założycielskim. ${ }^{9}$

Powieściopisarz przyjmuje więc rolę świadka drugiego stopnia, a trauma historyczna, ujęta w narrację, ukonkretnia się, budzi empatię i prowadzi do stawiania się „w sytuacji innego, rozumiejąc i uznając różnicę jego sytuacji, a przez to nie zajmując jego miejsca"10. W głośnej powieści Jeana Rouauda, Pola chwały (tytuł oryginału: Les Champs d'honneur), z roku 1990"11, padają słowa, które można odczytać jako manifest etyczny, w którym rozpozna się całe "postpamięciowe pokolenie ${ }^{12 "}$ pisarzy powracających do tematyki I wojny

7 Tamże, s. 130. Fragment, jak i pozostałe cytaty tekstów francuskich, jeśli nie podano inaczej, w przekładzie autora artykułu.

8 C. Trevisan "Nous, les seconds". La mémoire de la Grande Guerre dans le récit contemporain, w: Histoire culturelle de la Grande Guerre, dir. J.-J. Becker, Armand Colin, Paris 2005, s. 101.

9 Tamże, s. 113-114.

D. LaCapra Trauma, nieobecność, utrata, przeł. K. Bojarska, w: Antologia studiów nad trauma, red. T. Łysak, Universitas, Kraków 2015, s. 99-100. Powieść została uhonorowana nagrodą Goncourtów. 
z poczuciem winy wynikającej z zapomnienia i zobojętnienia: „Nigdy naprawdę nie wysłuchaliśmy tych dwudziestoletnich starców, których świadectwo umożliwiłoby także nam przemierzenie tej drogi koszmaru [...]"13. Odwołując się do obserwacji Dominica LaCapry na temat traumy historycznej, można w tym kontekście zauważyć, że literatura tworzona przez pisarzy francuskich należących do pokolenia wnucząt uczestników katastrofy z roku 1914, unaocznia proces odkrywania I wojny jako przechodzenia od świadomości nieobecności do doświadczania utraty. Dla poprzedniej generacji spustoszenie spowodowane Wielką Wojną nosi znamiona traumy strukturalnej, urazu kształtującego osobowość, ale jednocześnie przemilczanego. Figura podmiotu postpamięciowego $\mathrm{w}$ fikcjach autorów mierzących się dopiero na przełomie stuleci z ciężarem tamtych wydarzeń obrazuje wysiłek unarracyjnienia - w akcie estetycznym - dziedziczonej traumy, by móc spróbować w procesie żałoby może nie tyle przegnać widma, co uwolnić je z upiornej aury, ukonkretnić po umieszczeniu ich w historii, określeniu i nazwaniu jako „utrac[onych] inn[ych]"14.

W Polach chwaty metaforą nieuleczalności rany, niemożności zamknięcia pracy żałoby był obraz ekshumacji, która nie dawała pewności identyfikacji poszukiwanego ciała poległego na wojnie członka rodziny i jego ponownego pochówku, w celu ukonkretnienia w świadomości ocalałych straty oraz wyrwania umarłego z anonimowości zbiorowej mogiły. Natomiast w małych narracjach, do których się odwołam w dalszej części artykułu, kluczowym motywem jest ocalenie i wyobrażone spotkanie postpamięciowego podmiotu z żyjącymi, naocznymi świadkami I wojny. Ci ostatni albo pośredniczą w przywoływaniu duchów traumatycznej przeszłości, albo też sami się ukazują jako widma, których obecność ukonkretni narracja tworzona przez świadka drugiego stopnia. Dlatego też spektralność w omawianych tu tekstach literackich włącza się w proces postpamięciowego zmagania z traumą innego. Widmo unaocznia bowiem domagający się nazwania uraz poprzednich pokoleń, ale też uświadamia współczesnemu podmiotowi wagę dziedziczonej traumy w jego własnej tożsamości narracyjnej.W tym kontekście małe formy literackie, dzięki swobodnej relacji między fikcją i historią oraz łatwej

phone Literature and Culture, ed. A. Branach-Kallas and N. Strehlau, Cambridge Scholars Publishing, Newcastle upon Tyne 2015, s. 95.

13 J. Rouaud Pola chwały, przeł. E. Wende, PIW, Warszawa 1996, s. 128.

14 D. LaCapra Trauma, nieobecność, utrata, s. 85. Zob. także na temat traumy strukturalnej i traumy historycznej: K. Bojarska Sztuka niemożliwej możliwości, „Teksty Drugie” 2010 nr 5, s. 162. 
w odbiorze czytelniczym grze intertekstualnej z konwencjami gatunkowymi, zastępują, dedramatyzując jej nieobecność, opowieść międzypokoleniową.

\section{2.}

W roku 1929, Jean Norton Cru we wstępie do monumentalnej pracy Témoins, zawierającej analizę ponad 300 tekstów (artykułów prasowych, wspomnień, refleksji, listów i powieści) świadectw kombatantów podkreślał rozdźwięk między dominującymi narracjami o wojnie a rzeczywistością, na którą machina polityki i propagandy skazała młodych Francuzów:

Co do odwagi, patriotyzmu, ofiary, śmierci, zostaliśmy oszukani i gdy tylko po raz pierwszy znaleźliśmy się pod obstrzałem, natychmiast stało się dla nas jasne kłamstwo anegdoty, historii, literatury, sztuki, opowieści weteranów i oficjalnych dyskursów. To, co widzieliśmy, to, co przeżywaliśmy, nie miało nic wspólnego z tym, czego się spodziewaliśmy, na podstawie tego wszystkiego, co czytaliśmy i co na nam powiedziano. Nie, wojna nie jest rzeczą ludzką: to była oczywistość, której moc nas zmiażdżyła. ${ }^{15}$

Henri-Frédéric Blanc, w wydanej w roku 1999 nowelce Le Dernier Survivant de Quatorze [Ostatni ocalały z tysiąc dziewięćset czternastego] posługując się formą monologu, przypomina o stałej konieczności demaskowania utrwalonych dyskursywnie zafałszowań pamięci o traumie historycznej. Tekst ironicznie dekonstruuje mit weterana, zarówno jako epickiego bohatera, jak i niewinnej ofiary absurdalnego konfliktu. Narratorem jest ostatni żyjący, anonimowy uczestnik Wielkiej Wojny ${ }^{16}$, którego wspomnienia nagrywa siedząca przy jego szpitalnym łóżku młoda dziennikarka.

Podczas wywiadu ocalony odgrywa rolę medium przywołującego ducha wojny. „Cała przeszłość jest tu, - mówi starzec - kilka centymetrów od rzeczywistości"17. Będąc świadomym chropowatości swojej opowieści, weteran

15 J. Norton Cru Témoins. Essai d'analyse et de critique des souvenirs de combattants édités en français de 1915 à 1928, Eurédit, Paris 2015 (reprint), s. 13-14.

W rzeczywistości ostatni francuski uczestnik I wojny, Lazare Ponticelli, zmarł w roku 2008. Zob. B. Hopquin Lazare Ponticelli, le dernier poilu français, "Le Monde”, 12.03.2008, http://www.lemonde.fr/1914-1918-90-ans-apres-I-armistice/article/2008/03/12/lazare-ponticelli-le-dernierpoilu-francais-est-mort_1022170_736535.html, (9.11.2017). 
prosi dziennikarkę o dopracowanie stylistyczne nagranego materiału, lecz po chwili stwierdza, że narracja musi zostać przekazana w jej surowej formie z wszelkimi niestosownościami ${ }^{18}$. Jednakże problem nieprzystawalności konwencji językowej do niewyrażalnego i nieprzekazywalnego doświadczenia wojennego nie ogranicza się w tekście Blanca do imitacji chaotycznej mowy potocznej. Narrator okazuje się sprawnym retorem, a jego rozrachunek ze stereotypami historycznymi zaczyna się od odkłamania jednego z najbardziej utrwalonych wyobrażeń o Wielkiej Wojnie. Podkreśla on bowiem, że popularne określenie „poilu” (zarośnięty, nieogolony), pozornie potoczne, należy w istocie do języka propagandy manipulującego społecznym odbiorem wojny.

"zarośnięci”, to już było kłamstwo. Kłamstwo, by zamaskować młodziankobójstwo ${ }^{19}$. Nazywano nas „zarośniętymi”, ponieważ byliśmy zbyt smarkaci, by mieć zarost. [...] Oni chcieli ukryć naszą młodość, tak jakbyśmy już byli mężczyznami, a byliśmy tylko dziećmi. ${ }^{20}$

Kierując te słowa do dziennikarki, ostatni ocalony nie tylko ukonkretnia obraz wojennej traumy i na nowo kształtuje jej tożsamość narracyjną poprzez opowieść alternatywną wobec tradycyjnej symboliki upamiętniającej I wojnę, ale także zmniejsza dystans między swoim ,ja", uwolnionym z maski oficjalnego mitu, a młodym odbiorcą - świadkiem drugiego stopnia ${ }^{21}$.

Weteran gwałtownie zmienia stylistykę wypowiedzi, gdy przechodzi do wspomnień o bitwie pod Verdun. Stara się zobrazować „chaos połączony ze spustoszeniem" za pomocą poetyckich metafor i porównań, czym daje wyraz bezradności realistycznej narracji w zetknięciu ze światem, który zdaje się

18

19

Tamże, s. 10.

W tekście oryginalnym użyto neologizmu "jeunocide”, będącego grą słów "jeune” (młody) i „génocide" (ludobójstwo).

H.-F. Blanc Le Dernier Survivant de Quatorze, s. 11.

O postrzeganiu ofiar i weteranów Wielkiej Wojny przez pryzmat mitu „poilu” pisze także Jean Rouaud w eseju autobiograficznym Un peu la guerre, w którym odtwarza okoliczności powstania powieści Pola chwały. Autor wspomina, w jaki sposób I wojna była widziana przez młodych Francuzów z pokolenia maja '68. Obwieszeni medalami uczestnicy uroczystości rocznicowych 11 listopada byli dla nich godnymi szyderstwa „archetypami wstecznictwa”. Dopiero odkrycie wśród pamiątek rodzinnych śladów po poległych na I wojnie przodkach uświadomi przyszłemu pisarzowi, że śmieszni „poilus” byli w czasie wojny młodymi ludźmi, a ich losy to nie tylko karta oficjalnej, wielkiej Historii, ale jednostkowe tragedie ludzi dopiero wkraczających w dorosłość. Zob. J. Rouaud Un peu la guerre, Éditions Grasset \& Fasquelle, Paris 2014, s. 98-99, 157. 
stworzonym w umyśle wariata „zamkniętym przedpokojem niebytu"22. Wybujała ekspresyjność dyskursu w tej części noweli uwypukla reakcję narratora na doświadczenie blokady mowy. Pole bitwy pod Verdun, według jego relacji, było przestrzenią, gdzie „mówiły działa”, natomiast ludzie sprowadzeni do rangi „mięsnego materiału” zostali pozbawieni zdolności werbalizowania paraliżującego strachu. Niemoc, czy wręcz nieobecność mowy kontrastuje z rzeczywistością czasów wojny poza linią frontu, gdzie rządzi wszechobecny język kłamstwa („jakby śmierć pobudzała słowa”23), za pomocą którego także sam narrator stara się ocalić swoje życie.

Z równą zaciętością weteran atakuje klisze dyskursu, który pozornie potępia etos wojny, a w rzeczywistości usprawiedliwia jej autorów, przedstawiając krwawy konflikt światowych mocarstw w kategoriach samoczynnego żywiołu poza ludzką, rozumową kontrolą. Narrator stwierdza, że „wojna nie wybucha" ani też nie „wychodzi z ziemi”, lecz jest precyzyjnie obmyślaną, przygotowaną z rozmysłem przez konkretnych ludzi machiną ${ }^{24}$, podobnie jak „los” poszczególnych żołnierzy na froncie był „specjalnie wyprodukowany w milionach egzemplarzy" przez racjonalnie kalkulujących decydentów ${ }^{25}$. Odrzucając stereotypową wizję upadku cywilizacji, weteran oświadcza: „Wojna czternastego roku, panienko, nie była triumfem zdziczenia, ale czystego rozumu"26.

W końcowym rozrachunku monolog umierającego weterana w tekście Blanca pozwala przekazać i jednocześnie uwolnić traumę więzioną w języku kłamstwa. Napięcie między przemilczeniem i wyparciem urazu a potrzebą jego unarracyjnienia wyartykułowane jest najotwarciej pod koniec opowiadania. Po zdaniu: „Od tylu lat próbuję zapomnieć te dni bez imienia!”, następuje seria wyliczeń okropieństw wojennych tkwiących w pamięci ocaleńca. Każde z nich poprzedzone jest anaforycznym sformułowaniem „próbuję

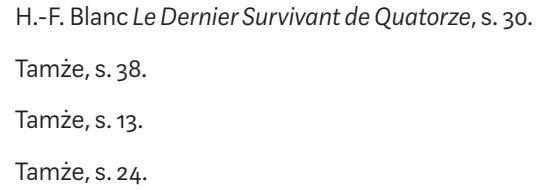
tacja genezy Zagłady według Zygmunta Baumana (por. Nowoczesność iZagłada, przeł. T. Kunz, Wydawnictwo Literackie, Kraków 2009, s. 13), kiedy, to co powszechnie nazywa się absurdem wojny, urasta do rangi esencji ludzkiego bytu. Starzec stwierdza bowiem, że "wojna nie jest bardziej absurdalna niż życie, to po prostu absurd bardziej skondensowany" (Le Dernier Survivant de Quatorze, s. 73). 
zapomnieć", powtarzającym się dwanaście razy na dwóch stronach tekstu ${ }^{27}$. Otrzymany w ten sposób efekt koszmarnej litanii współbrzmi z opisem walk, w którym narrator posługuje się słownictwem religijnym: „To była śmierć taśmowa. Przedmowa, wystawna inauguracja Apokalipsy. Jutrzenka niebytu. Działa zdawały się być inkwizytorami na Sądzie Ostatecznym" ${ }^{28}$. Wplecenie intertekstu biblijnego w antyepicką opowieść weterana o własnym tchórzostwie na polu bitwy i o bezwzględności francuskich oficerów wobec podlegających im żołnierzy służy tu parodiowaniu zakorzenionych w języku i kulturze uwznioślających obrazów I wojny. W tym przypadku Henri-Frédéric Blanc głosem swojego antybohatera demitologizuje tzw. religię wojny, czyli ideologię - wyrażaną $\mathrm{w}$ dyskursie publicznym i praktykach artystycznych poprzez wykorzystywanie symboliki biblijnej - łączącą fideizm z kultem ojczyzny i przedstawiającą walkę z Niemcami jako „krucjatę"29.

Monolog ocaleńca, mimo nasycenia goryczą, przynosi efekt terapeutyczny. Pod koniec spotkania z dziennikarką opowiada on z ironią o własnej podłości, strachu, przyznaje się do zabójstwa jednego z przyjaciół na froncie i relacjonuje groteskowo-makabryczne quid pro quo, w wyniku którego został uznany za bohatera wojennego. Doza czarnego humoru pozwala w dużym stopniu oddramatyzować widmo wojny i nakłonić świadka drugiego stopnia do próby oswojenia się z nim, do odczytania go na nowo, do wymazania z własnej tożsamości narracyjnej stron zapisanych językiem stereotypów. Obecność młodej dziennikarki jest w tekście zasygnalizowana jedynie poprzez kilka bezpośrednio adresowanych do niej zwrotów narratora, pełniących funkcję fatyczną, nie otwierających możliwości dialogu. Niemniej w wypowiedzi weterana ważną rolę odgrywają aspekty perlokucyjne świadczące o intencji doprowadzenia adresatki monologu, a wraz z nią czytelnika, do konfrontacji dwóch dyskursów pamięciowych: patetycznych, oficjalnych przekazów ukazujących Wielką Wojnę jako wspólną ofiarę Francuzów i traumatycznych wspomnień osobistych pojedynczego uczestnika wojennego koszmaru.

27 Tamże, s. 69-70.

28 Tamże, s. 71.

29 Por. A. Becker La Guerre et la foi. De la mort à la mémoire, 1914-1939, Armand Colin, Paris 1994; A. Becker, S. Audoin-Rouzeau 14-18, retrouver la Guerre, Gallimard (Folio), Paris 2000, s. 159-185, E. Fouilloux Première Guerre mondiale et changement religieux en France, w: Histoire culturelle de la Grande Guerre, dir. J.-J. Becker, Armand Colin, Paris 2005, s. 118-119; E. Godo La guerre de 14-18: une crise de l'esprit?, „Études. Revue de Culture Contemporaine” 2016 no. 6, s. 75-86. 
3.

Krótki esej autobiograficzny Gisèle Bienne, L'auteur et ses autres [Autor i jego inni], rozpoczyna się stwierdzeniem:

Jest to co istnieje, przed-istnieje, to co było „przed”. Przed naszą praktyką czytania, przed naszą praktyką pisania, przed każdą naszą praktyką artystyczną. Są miejsca, świat, rodzina, to, w czym jesteśmy zanurzeni nie widząc tego dobrze, nie uchwytując, a co, pewnego dnia, zaczyna nas dotyczyć. ${ }^{30}$

W owym „przed” kształtującym wrażliwość, tożsamość narracyjną i w konsekwencji twórczość literacką Bienne kluczową rolę odgrywają białe plamy historii rodzinnej, przemilczane tragedie, w tym doświadczenia przodków wyniesione z I wojny ${ }^{31}$. Stawiając się w roli świadka drugiego stopnia, pisarka podejmuje wysiłek zmierzenia się z powojenną traumą dwóch pokoleń - dziadków, których osobiście nie znała i rodziców, którzy nie byli w stanie werbalizować powojennych urazów psychicznych. W jej wspomnieniach z dzieciństwa tajemniczy przodkowie, zmarli jawią sięjako obecne w domu cienie, „milczące zgromadzenie, obdarzone tajemniczą siłą"32. Dlatego, jak wyzna autorka w czasie jednej z dyskusji panelowych, jej zainteresowanie wojną wynikało z potrzeby poznania przeszłości dziadków i zrozumienia milczenia ojca. Pierwszym impulsem było odkrycie w domu, „w zakazanym miejscu”, pamiątek po przodkach poległych na I wojnie, ich wdowach oraz munduru dziadka wujecznego, który został uznany za zaginionego na froncie. Bienne wspomina:

Byłam w królestwie zmarłych [...], wyobrażałam sobie ich życie. Wskrzeszałam ich, życzyłam im, by przeżywali miłości, które miały trwać długo, kochałam ich i myślałam, że oni mnie kochają. Między dziewiątym a czternastym rokiem życia jest się w wieku, kiedy potrzebni są nam przodkowie. $^{33}$

G. Bienne L'auteur et ses autres, w: Gisèle Bienne. Figures de l'altérité, dir. C. Rannoux, Presses Universitaires de Rennes (seria La Licorne, nr 95), Rennes 2011, s. 11.

Tamże, s. 16.

Tamże, s. 17-18.

33 Wypowiedź Gisèle Bienne zapisana w: I. Arickx Table ronde à la Villa Marguerite Yourcenar, w: La Grande Guerre. Un siècle de fictions romanesques. Actes du Colloque 13-15 mars 2008 Université de Gand - In Flanders Fields Museum, Ypres, dir. P. Schoentjes, Librairie Droz, Genève 2008, s. 410. 
Autorka wskazuje także na znaczenia dla jej pisarstwa widmowej atmosfery Reims, gdzie zamieszkała w wieku dorosłym, miasta zniszczonego w sześćdziesięciu procentach w wyniku bombardowań w latach 1914-1918. Tam, jak mówi Bienne, nauczyła się „odszyfrowywać ślady wojny”34.

W opublikowanej w roku 2004 powieści Paysages de l'insomnie (Krajobrazy bezsenności) pisarka przedstawia sytuację, w której werbalizacja nie może być skutecznym środkiem łagodzenia skutków urazu ${ }^{35}$. Główny bohater, Marcel, po powrocie z frontu nie jest w stanie uwolnić się z depresji i obsesyjnie nawiedzających go obrazów wojennego horroru. W poczuciu alienacji wśród najbliższych i w społeczeństwie stopniowo zapominającym o katastrofie, wraz z trójką innych weteranów zamyka się we własnym mikroświecie, gdzie widmo wojny „nie jest wspomnieniem, ale czymś na kształt wiecznej teraźniejszości"36. Inwalidzi opowiadają sobie wzajemnie stale te same historie frontowe, mając wrażenie, że przywołują duchy poległych współtowarzyszy, a "mowa zmarłych" nie przestaje „współbrzmieć z ich słowami”, przez co „teraźniejszość cofa się, staje się przeszłością, a przeszłość staje się teraźniejszością"37. Nikt spoza ich hermetycznego kręgu nie może być odbiorcą tych narracji, które pełnią podobną funkcję jak analizowane przez Carine Trevisan listy żołnierzy pisane z frontu I wojny. Francuska badaczka stwierdza, że przede wszystkim były one „świadectwem dla samego świadka”, który poprzez pisanie o traumatycznych doświadczeniach upewniał samego siebie o ich realności i swego faktycznego uczestnictwa w wydarzeniach wydających się wytworem obłędu ${ }^{38}$. Werbalizacja urazu, wyrażając napięcie między wątpieniem i pewnością, jest równocześnie reakcją na wrażenie unicestwienia „ja” jako podmiotu ${ }^{39}$. Natomiast w krótkiej powieści Gisèle Bienne adresowanej do młodych czytelników, Le cavalier démonté [Kawalerzysta zsadzony z konia], wydanej w roku 2006, obecność, u boku weteranów, dziecka

Tamże, s. 411.

Por. C. Rannoux Imaginaire des mots, poétique du nom propre, Rémuzor, Paysages de l'insomnie, La Ferme de Navarin, w: Gisèle Bienne. Figures de l'altérité, s. 45-47.

G. Bienne Paysages de l'insomnie, Éditions Climats, Castelnau-le-Lez 2004, s. 52.

Tamże, s. 57.

Zob. C. Trevisan Se rendre témoignage à soi-même, w: J.-F. Chaintaretto, C. Trevisan, J. Altounian, R. Waintrater, P. Réfabert Témoignage et trauma. Implications psychanalitiques, Dunod, Paris 2004, s. 2.

Tamże, s. 3-4. 
- świadka drugiego stopnia otwiera perspektywę przekazu i uwolnienia traumatycznych wspomnień ${ }^{40}$. Narratorką jest Lucile, dorastająca dziewczyna, której rodzice zabraniają kontaktów z jej dziadkiem Félicien'em, gdyż nadużywa on alkoholu, jest niekomunikatywny i budzi postrach otoczenia nieprzewidywalnymi atakami gniewu. To wszystko - jak wkrótce uzmysłowi sobie wnuczka - jest syndromem niezabliźnionego psychicznego urazu po I wojnie. W roku 1964, wbrew zakazowi nastolatka nawiązuje z nim coraz bliższą więź. Félicien wprowadza ją w objętą tabu przestrzeń - bar, gdzie regularnie się upija w towarzystwie trzech inwalidów wojennych, którzy, podobnie jak postacie z Paysages de l'insomnie, w niekończących się opowieściach przywołują widma poległych żołnierzy. Słuchając przekazywanych chaotycznym, emocjonalnym językiem historii weteranów, nastolatka zmuszona jest zweryfikować swoje wyobrażenie o wojnie ukształtowane stereotypową, podręcznikową narracją, w której wszystko było „czyste i uregulowane"41. Bohaterka, podobnie jak dziennikarka w Le Dernier Survivant de Quatorze, odkrywa rozdźwięk między utrwalonymi w wyobraźni zbiorowej kliszami językowymi na temat I wojny a jej percepcją z punktu widzenia uwięzionego w traumatycznych wspomnieniach ocaleńca. Félicien sprzeciwia się nawet używaniu najbardziej emblematycznego sformułowania „Wielka Wojna”, widząc w nim środek manipulacji pamięcią zbiorową ${ }^{42}$. Weterani snują też ironiczne rozważania o innych, alternatywnych terapeutycznych sposobach narratywizacji traumy. Dyskutują np. o projekcie książki napisanej wspólnie przez Niemca i Francuza albo o farsie na temat wojny ${ }^{43}$.

Inaczej niż dzieje się w noweli Blanca, rola świadka drugiego stopnia nie sprowadza się tu do pozycji biernego odbiorcy monologu. Lucile, według dziadka, jako przyszła pisarka, może stać się pośredniczką międzypokoleniowej, odkłamanej narracji o wojnie. W tym celu Félicien zabiera wnuczkę w podróż do Szampanii, w rejon dawnej linii frontu. Kulminacyjnym punktem ich wędrówki jest miejsce, gdzie znajdował się folwark zwany „La Ferme de Navarin". Tam w sierpniu 1915 Blaise Cendrars trafiony niemieckim pociskiem

40 Por. C. Rannoux Imaginaire des mots, poétique du nom propre, s. 48; G. Theeten La Mémoire de la Grande Guerre dans les romans de Gisèle Bienne, w: Gisèle Bienne. Figures de l'altérité, s. 57;

D. Viart En quête du passé: la Grande Guerre dans la littérature contemporaine, w: La Grande Guerre. Un siècle de fictions romanesques, s. 328. 
stracił prawe ramię. Do przeżyć wojennych z tego okresu pisarz powracał w tekstach autobiograficznych, m.in. w utworach Odcięta ręka, Rażony gromem, Krwawitem, które dla Gisèle Bienne, jak i dla stworzonej przez nią postaci, odgrywać będą rolę substytutu rodzinnych świadectw. W Le Cavalier démonté doświadczenia wojenne Cendrarsa i innych poetów - uczestników bitwy nad Marną - Apollinaire'a, Aragona, o których weteran opowiada wnuczce w czasie podróży, otwierają możliwość alternatywnego zwerbalizowania traumy poprzez wpisanie własnej narracji w sieć intertekstów. Z punktu widzenia Lucile będą one środkiem interpretacji i konkretyzacji widmowej przeszłości. Wśród konsekwencji traumy uniemożliwiającej mu reintegrację społeczną, Félicien wymienia m.in. afonię potęgującą odczucie braku możliwości komunikowania się z otoczeniem w rzeczywistości powojennej44. Ten szczegół wyraziście uzasadnia wybór ekspresjonistycznego, wielogłosowego pisarstwa Cendrarsa, w którym weteran w pewnej mierze ogląda samego siebie oczami innego, jako remedium na blokadę mowy ${ }^{45}$.

Do postaci i twórczości autora Odciętej ręki Gisèle Bienne powróciła w innej krótkiej formie prozatorskiej - w utworze La Ferme de Navarin opublikowanym w roku 2008. W tym przypadku fikcja biograficzna ${ }^{46}$ jest jednocześnie rodzajem intelektualnej autobiografii pisarki komentującej wpływ Cendrarsa, w różnych okresach jej życia, na jej wrażliwość i przyszłą pracę literacką. W opowieść o swojej podróży do folwarku Navarin Bienne wplata cytaty i parafrazy fragmentów Prozy transsyberyjskiejkolei i małej Żanny z Francji - poematu prozą o wyprawie poety z Moskwy do Charbinu podczas wojny japońsko-rosyjskiej, której obrazy nasuwają autorce skojarzenia z Wielką Wojną ${ }^{47}$. Ekspresyjność tekstu Cendrarsa kontrastuje jednocześnie z atmosferą przejmującej ciszy, gdy Bienne opisuje tereny dawnej linii frontu.

44 Tamże, s. 58.

45 Por. C. Rannoux Imaginaire des mots, poétique du nom propre, s. 48-51.

46 Tym terminem D. Viart definiuje przynależność gatunkową La Ferme de Navarin. Zob. D. Viart En quête du passé, s. 330.

47 Zob. G. Bienne La Ferme de Navarin, Gallimard, Paris 2008, s. 29. Podobnie widział to Adam Ważyk, tłumacz poematu: „Proza transsyberyjskiej kolei i małej Żanny z Francji ukazała się w 150 egzemplarzach w 1913. Mogłoby się wydawać, że jak na młodego Szwajcara i poetę francuskiego - ta podróż na spotkanie wojny rozgrywającej się na Dalekim Wschodzie to dość szczególna przygoda. W rok po ukazaniu się poematu wojna miała się stać doświadczeniem całego pokolenia i Cendrars miał stracić w bitwie prawą rękę. W poemacie transsyberyjskim są obrazy, które brzmią jak przeczucie tego okaleczenia". A. Ważyk Przedmowa, w: B. Cendrars Poezje wybrane, Ludowa Spółdzielnia Wydawnicza, Warszawa 1977, s. 12. 
Widzi tam ziemię słabo skrywającą "szkielet śmierci ${ }^{48 ”}$. Podczas "podróży do nieżywych" pisarka ma wrażenie, że kołami samochodu jedzie po ciałach żołnierzy, których „nigdzie nie ma, albo raczej, oni są tu wszędzie [...]. Wycofani na no man's land wilgotnej i zimnej okolicy, nie hałasują, są w pułapce Historii [...]. Pozostawiono ich tam"49.Z determinacją wkracza w świat, ,widmowych ruin, wymownych śladów przeszłościco", wraz z cieniami zmarłych poetów, uczestników wojny, przemierza „przeklętą, ale posiadającą urzekającą siłę okolicę", „ziemię zapomnienia i wspomnien" ${ }^{51}$, w którą się wczytuje jak „w książkę" 52. Gra intertekstualna, w którą Bienne włącza Cendrarsa z jego utworami o I wojnie oraz Apollinaire'a i Aragona, otwiera drogę powrotu do dziecięcych fantazji snutych pod wpływem wspomnianego wcześniej odkrycia w domu sekretnego miejsca, gdzie ukryte były pamiątki po ofiarach wojny ${ }^{53}$. Narracja w obu przypadkach - w wyobraźni dziecka i w tekście biofikcyjnym - uwalnia widmową przeszłość z opresyjnej ciszy. W La Ferme de Navarin Bienne wspomina: „Dotykałam się śmierci, dotykałam się życia. [...] Zbratałam się z nieżyjącymi, nauczyłam się ich kochać. Wymyślałam im harmonijne życie [...]"54. Otwarta i lekka forma małej narracji,jaką jest biografia fikcyjna, pozwalająca na swobodne przemieszczanie się między gatunkami i rejestrami językowymi ułatwia, także na poziomie języka, zbliżenie się do świata wojny. Wymownym tego przykładem są lakoniczne, a jednocześnie przepełnione emfazą słowa na tablicy informacyjnej: „ICI FUT LA FERME DE NAVARIN ${ }^{55 "}$ - TU BYŁ FOLWARK NAVARIN. Przekład na język polski nie oddaje złożoności skojarzeń wywołanych przez ten pozornie przezroczysty i neutralny semantycznie tekst. Użyty w nim czas gramatyczny - passé simple (przeszły prosty) - pełniący funkcję aorystu ma charakter par excellence literacki, archaizujący i konotuje język wzniosły, podporządkowany ścisłym konwencjom dyskursywnym i estetycznym. Dlatego biografka stwierdza, że

G. Bienne La Ferme de Navarin, s. 37.

Tamże, s. 16. 
passésimple wywołuje na niej „dziwne wrażenie"56 . Gramatyka stawia tu barierę między traumą uczestnika wojny a pisarzem/czytelnikiem upominającym się o prawo do bycia świadkiem drugiego stopnia. Symboliczne uwięzienie narracji o przeszłości w strukturze aorystu w tym kontekście oznacza brak możliwości stworzenia relacji interpersonalnej. Jest to bowiem konwencja, jak to określał Émile Benveniste, wykluczająca formy „ja" $i$,ty”, stosowana do narracji bezosobowej, precyzyjnej, czysto faktograficznej, ściśle oddzielającej płaszczyznę czasową relacjonowanego wydarzenia od czasu, w którym dokonuje się akt wypowiadania ${ }^{57}$. Dla Bienne natomiast akt pisarski ma znieść granicę między nią samą a Historią, Cendrarsem i zmarłymi, „którzy mogą do nas jeszcze przemawiać jedynie w niektórych książkach"58.

Widmowość w La Ferme de Navarin ukazuje swój inny wymiar, gdy odtwarzając losy autora Odciętej ręki, pisarka opowiada o obsesyjnych wspomnieniach nawiedzających go po powrocie $\mathrm{z}$ frontu. Bienne nawiązuje także do udziału Cendrarsa w realizacji niemego filmu z roku 1919 J'accuse [Oskrżam], w którym reżyser, Abel Gance, ilustruje wszechobecność spowodowanego przez wojnę urazu w upiornej, apokaliptycznej scenie powrotu ożywionych trupów żołnierzy. Podczas gdy dla żywych w J'accuse widma oznaczają akt oskarżenia ${ }^{59}$, Bienne wspomina film Gance'a, wyrażając pragnienie, by duchy poległych ukazały się wokół folwarku Navarin. Ich niewygodna obecność miałaby unaocznić napięcie między bezwyrazowym charakterem oficjalnego miejsca pamięci a empatyczną, osobistą, małą narracją postpamięciową ${ }^{60}$.

W Odciętej ręce, tekście wojennym Cendrarsa najczęściej bezpośrednio przywoływanym w La Ferme de Navarin, wbrew temu co można byłoby sądzić na podstawie jego tytułu, autor nie skupia się na własnych cierpieniach, lecz tworzy przejmujące portrety współtowarzyszy z frontu, przedstawiając każdego z nich, jak to komentuje Bienne, „z ranami i z radością życia”61. O swoim okaleczeniu wspomina zdawkowo: „Miesiąc później, pod koniec

\footnotetext{
56 Tamże.

57 Por. E. Benveniste Problèmes de linguistique générale, 1, Gallimard, Paris 1966, s. 237-250.

58 G. Bienne La Ferme de Navarin, s. 44.

59 Por. L. Véray La Grande Guerre à l'écran. Entre reconstruction du passé et lecture du présent, w: La Grande Guerre. Un siècle de fictions romanesques, s. 358-364.

60 Zob. G. Bienne La Ferme de Navarin, s. 98-99.

61 G. Bienne Cendrars: La main coupée, le grand livre, w: La Grande Guerre. Un siècle de fictions romanesques, s. 108.
} 
września, Ségouâna zginął w ataku na folwark Navarin, gdzie ja straciłem rękę" 62 . Sam tytuł książki nie odnosi się do tego wydarzenia. Obraz oderwanej kończyny pojawia się w innej scenie, której realizm przemienia się w alegorię całego niepojmowalnego horrendum wojny. Cendrars wspomina jak chwilę wytchnienia od walk, w pewien spokojny, czerwcowy poranek, przerywał niespodziewany widok:

[...] tkwiąc w ziemi niczym wielki rozwinięty kwiat, czerwona lilia, ludzka ręka ociekająca krwią, prawa ręka ucięta powyżej łokcia, o dłoni jeszcze żywej, wpijała się w grunt palcami, jak gdyby próbując zapuścić korzenie, i ta krwawa łodyga kołysała się łagodnie, zanim złapała równowagę ${ }^{63}$

Szczegółowy opis cierpień spowodowanych zranieniem i amputacją pojawia się w opowiadaniu Krwawiłem: „moje odcięte ramię tak bardzo mnie bolało, że gryzłem się w język, żeby nie krzyczeć" ${ }^{64}$. W La Ferme de Navarin motyw bólów fantomowych odczuwanych przez Cendrarsa po stracie ramienia nabiera znaczenia metaforycznego, staje się autotematyczną reprezentacją możliwego/niemożliwego aktu pisania o wojennym urazie ${ }^{65}$.

4.

W mikroopowiadaniach, z których składa się wydana w roku 2007 książka Cathie Barreau Visites aux vivants [Odwiedziny u żyjących], to nie zjawy przeszłości nawiedzają teraźniejszość, lecz narratorka-pisarka wyobraża samą siebie w postaci ducha przenoszącego się do czasów młodości pokolenia jej dziadków. Gra z konwencją bajki magicznej umożliwia włączenie

B. Cendrars Odcięta ręka, przeł. J. Rogoziński, w: B. Cendrars Odcięta ręka i inne wojenne opowieści, Noir sur Blanc, Warszawa 2014, s. 45.

63 Tamże, s. 234-235.

64 B. Cendrars Krwawiłem, przeł. J. Giszczak, w: tamże, s. 289.

65 Jak zauważa Dominique Viart, fikcja biograficzna stanowi jedną ze współczesnych strategii pisania o I wojnie, które odwracają problem relacji między autentyzmem świadectwa a literaturą. Odnosząc się do krytycznej opinii Nortona Cru na temat literackości nieuchronnie zafałszowującej obraz przeżyć wojennych, Viart stwierdza: „To już nie fikcja kontaminuje świadectwo [...], ale pisarze, którzy posługują się intertekstualnością literacką, by podtrzymać «fikcję świadectwa», tam gdzie samo świadectwo stało się niemożliwe". D. Viart En quête du passé, s. 335 . 
w postpamięciowe biofikcje fantazmatycznych, alternatywnych scenariuszy losów przodków okaleczonych przez wielką Historię.

Visites aux vivants otwiera wspomnienie ostatnich chwil życia Célestine, babki ze strony ojca, która przyszłej pisarce i innym bliskim zgromadzonym przy jej łóżku, w roku 1967, zaczyna opowiadać o traumatycznych przeżyciach z czasów I wojny. Funkcja empatyczna aktu pisania, jako symbolicznego dialogu świadka drugiego stopnia z nieżyjącym przodkiem, wyraża się poprzez splecenie dwóch form - pierwszoosobowej i trzecioosobowej - narracji. Gdy narratorka pisze o niezabliźnionej traumie Emmanuela, dziadka ze strony ojca, rannego podczas I wojny, intertekstualność, podobnie jak u Gisèle Bienne, substytuuje symbolicznie terapeutyczną werbalizację świadectwa i pośredniczy w procesie rekonstruowania wydarzeń, które nie zostały przekazane w opowieściach rodzinnych:

[Emmanuel] o niczym nie opowiada. Ludzie u mnie nie są rozmowni. Bo lepiej jest milczeć o cierpieniach. [...] I na tym chyba polega tajemnica ciszy: nie zadawano pytań ze strachu, by nie przeszkadzać, by nie otwierać trudnej do zagojenia rany, bo nie będzie się wiedziało co zrobić z usłyszanymi zwierzeniami [...]. A więc trudno jest zacząć opowiadać o nienazywalnym. Nic nie wiem o wojnie Emmanuela, ale tyle o niej czytałam, że wydaje mi się, że widzę go, małego, zagubionego, milczącego pośród współtowarzyszy żołnierza $[\ldots]^{66}$

Pisarka czuje się zobowiązana do uczynienia z przodków postaci literackich, a samo pisanie jest działaniem, które ma pozwolić „wziąć rewanż” na Historii ${ }^{67}$. Jednym z przykładów fantazmatycznego gojenia rany jest wizja samego procesu tworzenia tekstu jako zbawiennej reakcji na obecny w pamięci rodzinnej uraz związany z analfabetyzmem. Narratorka przywołuje skargę babki Clarisse, która w wieku dziewięćdziesięciu lat zwierzyła się z ciągle tkwiącego w niej poczucia straty, jaką była dla niej nieumiejętność czytania i pisania. To upokarzające ograniczenie ściśle wiąże się ze wspomnieniami z roku 1914, ponieważ to właśnie wybuch wojny uniemożliwił jej rozpoczęcie szkolnej nauki. Kiedy narratorka odwołuje się do tych wydarzeń, zaczyna wyobrażać sobie Clarisse, obecną przy niej, śledzącą na ekranie komputera zapisywany

C. Barreau Visites aux vivants, Éditions Laurence Teper, Paris 2007, s. 77.

67 Tamże, s. 22. 
tekst ${ }^{68}$. Mała narracja, w którą Barreau wplata elementy baśniowości, może być tu porównana do aktu czarowania służącemu, jak to określa Hans Ulrich Gumbrecht, kreowaniu obecności ${ }^{69}$. Gumbrecht przywołuje praktyki magiczne, jako drugie, oprócz narracji medium historii. W mikroświecie Visites aux vivants odzwierciedla się także dążenie do uobecnienia i odkupienia. Tym pierwszym pojęciem Gumbrecht określa sposoby prezentyfikacji przeszłości za pomocą środków alternatywnych wobec dyskursu histograficznego, czyli np. poprzez zgromadzone przedmioty, których „można dotknąć i wobec których znajdujemy się w przestrzennej bliskości"70. Odwołanie się do konwencji bajki magicznej w sposobach tematyzowania widmowości w utworze Cathie Barreau wyraża pragnienie utrwalenia małych historii rodzinnych, po których nie pozostały ślady w postaci tekstów - dokumentów, listów, pamiętników i innych materialnych dowodów przeszłości. Akt opowiadania ma więc, w tym kontekście, stać się formą uobecniania. Według Gumbrechta

odkupienie jest tropem, który sugeruje specyficzny stosunek do przeszłości, akceptację odpowiedzialności za czyny, których sam nie dokonałem. [...] odkupienie może nastąpić tylko w sytuacji, kiedy dokonuje się uobecnienie. Nie ma odkupienia bez uczynienia przeszłości na powrót dotykalnej, bez przywrócenia obecności przeszłości. [...] Odziedziczyłeś po przeszłości coś, co przynosi wstyd, a nawet więcej, ponieważ wstyd byłby najsłabszym rodzajem reakcji, której nie można kontrolować, tak samo jak twoje poczucie winy za coś, czego nie zrobiłeś. ${ }^{11}$

Fikcjonalne, po części baśniowe, przywoływanie skutków Wielkiej Wojny dla małych dramatów rodzinnych spełnia porównywalną funkcję, łącząc odkupienie $\mathrm{z}$ innym procesem, którego metaforą jest w Visites aux vivants także pojęcie zaczerpnięte $z$ intertekstu religijnego - zmartwychwstanie ${ }^{72}$.W świecie Barreau zmarli nie zakłócają świata żywych. Baśń ich ożywia, unarracyjnia

68 Tamże, s. 16-17.

69 H.U. Gumbrecht Użyteczność historii (uobecnienie i odkupienie), przeł. E. Domańska, w: Pamięć, etyka i historia. Anglo-amerykańska teoria historiografii lat dziewięćdziesiątych (Antologia przekładów), red. E. Domańska, Wydawnictwo Poznańskie, Poznań 2006, s. 123.

70 Tamże, s. 118. 
ich urazy i radości, otwiera i zabliźnia rany, odtwarza zerwane więzi. Jednakże widmowość ujawnia swój inny, mniej oswajalny, bardziej niepokojący wymiar. Kiedy narratorka przenosi się pod postacią ducha do przeszłości, ma smutną świadomość, że Wielka Wojna będzie dopiero początkiem serii historycznych katastrof XX wieku. I stwierdza:

Jest się mniej nieszczęśliwym, gdy żyje się w teraźniejszości, z tymi, którzy są blisko nas i tylko z nimi. Ja nie mam tej zdolności. Jestem w dziesięciu miejscach naraz, w dziesięciu okresach dziejowych naraz, nie wiedząc o tym. Piszę więc, by spróbować uporządkować te różne czasy, jednocześnie wyobrażone i bardzo rzeczywiste. ${ }^{73}$

Cathie Barreau rozwija motyw powtarzalności dramatów podmiotu uwięzionego w Historii w wydanej w 2014 powieści Comment fait-on l'amour pendant la guerre? [Jak się kocha w czasie wojny?] opatrzonej mottem zapożyczonym od Hélène Cixous: „Pokój to uśpiona wojna"74. Autorka powraca do koncepcji pisania, porównanego do "odkopywania umarłych", jako aktu dokonywanego "pomiędzy wojnami", w celu wyrażenia pragnienia odmienienia Historii, rozbicia "chronologii, by zagłębić się w czasie ludzkim"75. Nielinearna narracja powieści łączy traumatyczne wydarzenia rozgrywające się w różnych miejscach, na kilku płaszczyznach czasowych. Główna bohaterka powieści, pisarka Donatienne, podobnie jak narratorka w Visites aux vivants posiada zdolność wyostrzonego dostrzegania zatartych śladów przeszłości. W Nantes, gdzie mieszka, ma wrażenie, że widzi ruiny zbombardowanych w roku 1943 dzielnic. W otaczającej ją rzeczywistości widma dramatów przeżytych przez przodków podczas dwóch wojen światowych współistnieją z jej osobistymi wspomnieniami wojny libańskiej. Donatienne pisze powieść o miłości dwojga młodych ludzi, muzułmanki i chrześcijanina w Bejrucie w latach 1980. W tym samym czasie jej partner, libański dziennikarz Jad, noszący głęboko wrosły w psychikę uraz wojenny, z trudem zmaga się z zadaniem relacjonowania wciąż na nowo wybuchających krwawych konfliktów na Bliskim Wschodzie. Kreacja świata literackiego łączy się więc w świadomości Donatienne z koniecznością ujęcia w narrację wszystkich wojen, począwszy od roku 1914

Tamże, s. 83.

C. Barreau Comment fait-on l'amour pendant la guerre?, Buchet Chastel, Paris 2014, s. 9.

Tamże, s. 11-12. 
po drugą dekadę XXI wieku. Jednakże pisanie o wojnie oznacza tu również opowiadanie historii o ocaleniu. W takim kontekście pisarka zestawia ze sobą dwa wspomnienia nasuwające skojarzenie z nowotestamentową sceną zmartwychwstania:

27 lutego 1917, pod Verdun, dziadek Donatienne wpada do leja po pocisku. 17 lipca 1982, w Bejrucie, dziadek Jada jest przysypany pod gruzami. Jeden i drugi pozostają trzy dni skuleni w ciemności. Słyszą głosy, ale boją się i się nie ujawniają. Zostają odnalezieni trzeciego dnia w samo południe i uratowani. ${ }^{76}$

Wybuch wojny w Syrii sprawi, że to, co Donatienne postrzegała jako zamieszkujące jej wyobraźnię oswajalne widmo przeszłości, przemieni się w bolesną rzeczywistość. Gdy dowiaduje się, że Jad zaginął podczas prac dziennikarskich na terenach objętych konfliktem, na postpamięciowy obraz cierpienia kobiet wyczekujących, podczas I i II wojny, z niepokojem wieści o losach ich bliskich, nakłada się jej osobiste doświadczenie. Zwieńczeniem tej historii jest ponownie ocalenie. Jednakgdy kochankowie odnajdują się po uwolnieniu Jada z syryjskiego więzienia, Donatienne nie potrafi nakłonić go do dialogu i podzielania się bolesnymi przeżyciami: „Jeśli nawet Jad zwracał się do niej, to było tak jakby mówił do samego siebie, bez żadnych emocji. Kolejny raz, nie ma opowieści, pomyślała Donatienne. Wojna nie jest opowieścią. Wojna to niemoc życia, mówienia, pisania"77. Kolejny raz literatura w zastępstwie oczyszczającego świadectwa będzie stawiać czoła (nie)oswajalnym widmom jeszcze jednej wojny.

\section{5.}

Jeffrey C. Alexander w rozważaniach nad traumą kulturową stwierdza: „Póki praca nad znaczeniem ma miejsce w rzeczywistości estetycznej, jest ono kanalizowane przez określone gatunki i narracje, których celem jest wywołanie identyfikacji w wyobraźni oraz emocjonalnego katharsis"78. Małe fikcje i biofikcje Blanca, Bienne i Barreau odznaczają się, na tle innych utworów

\footnotetext{
76 Tamże, s. 136.

77 Tamże, s. 147.

78 J.C. Alexander Trauma kulturowa i tożsamość zbiorowa, w: Znaczenia społeczne. Studia z socjologii kulturowej, przeł. S. Burdziej, J. Gądecki, Nomos, Kraków 2010, s. 210.
} 
literackich podejmujących tematykę traumy wojennej, antyepickością uwidaczniająca dążenie do dedramatyzacji Historii i uwolnienia pamięci z jej sideł. Inaczej niż ma to miejsce w powieściach z lat 1980-1990 omawianych przez Carine Trevisan ${ }^{79}$, w których pisanie o cierpieniach ma znamiona przymusu narzuconego przez zmarłych, w małych narracjach postać świadka drugiego stopnia jest przedstawiona mniej jako podmiot nawiedzany przez widmo I wojny, a bardziej jako przywołujący jej duchy, podejmujący, z różnym skutkiem, próbę ich oswojenia, włączenia we własną historię. Praca fikcji jeśli nie prowadzi do symbolicznego uleczenia traumy, to ułatwia pogodzenie się ze świadomością nieprzemijalności śladów pozostawionych przez przeszłość. Dziedzictwo urazu przeistacza się z bolesnego ciężaru w bogactwo, jakim jest, zgodnie ze sformułowaniem Derridy, konieczność i możliwość liczenia się $\mathrm{z}$ duchami ${ }^{80}$. Widmowość przestaje, w małych narracjach, być figurą niemej skargi. Fikcja przywraca bowiem duchom ich język i głos ${ }^{81}$. W tym celu w autotematycznych tekstach Blanca, Bienne i Barreau akty mowy, powtórzenia i interteksty pełnią pierwszoplanową funkcję w procesie konstruowania świadectw drugiego stopnia. W przeciwieństwie do fikcji o I wojnie z nurtu neofantastycznego ${ }^{82}$, spektralność nie jest tu figurą abiektu ${ }^{83}$. Jednakże niepokój jaki wdziera się do małych narracji, wynika z przekonania o nieuchronności powrotu Historii z jej niszczycielską mocą. Hauntologiczne nawroty katastrofy 1914 roku, wyzierające spod innych traum, świadczą, że

79 Utwory przywoływane przez Trevisan: Pola chwały Jeana Rouauda (1990), cztery powieści Pierre'a Bergounioux - La Maison rose (1987), L'Orphelin (1992), La Toussaint (1994), Le Bois du chapitre (1996), pośmiertnie wydana, niedokończona powieść autobiograficzna Alberta Camusa Pierwszy człowiek (tytuł oryginału: Le Premier homme, 1994), La Chambre des officiers (1999) Marca Dugain, Stèle de Louis Bertin (2000) Fabre'a Bernarda, Le Retour du permissionnaire (1999) Gérarda Mordillata, Le Désir de guerre (1999) Frédérica Roux, dwie powieści Claude'a Simona L'Acacia (1989) i Le Tramway (2001). Zob. C. Trevisan "Nous, les seconds”. La mémoire de la Grande Guerre dans le récit contemporain.

80 J. Derrida Widma Marksa. Stan długu, praca żałoby i nowa Międzynarodówka, przeł. T. Załuski, PWN, Warszawa 2016, s. 16.

81 Tamże, s. 29.

82 Zob. G. Theeten La Grande Guerre en fiction. La représentation de la Première Guerre mondiale dans la littérature française de l'extrême contemporain. Thèse de doctorat sous la direction de P. Schoentjes, Université de Gand, Gand 2009, s. 207-239 (https://biblio.ugent.be/publication/4128792/file/4333508.pdf).

83 Zob. A. Branach-Kallas, P. Sadkowski La possession par les "pouvoirs de l'horreur" de la Grande Guerre, „Romanica Silesiana” 2016 nr 11 (t. 1), s. 207-216. 
uraz I wojny w kulturze francuskiej domaga się nadal przepracowania. W tym też kontekście fikcje literackie realizują Derridiańską zasadę odpowiedzialności nie tylko przed widmami zmarłych, ale także przed potencjalnymi ofiarami różnych form przemocy w przyszłości ${ }^{84}$.

\section{Abstract}

\section{Piotr Sadkowski}

NICOLAUS COPERNICUS UNIVERSITY (TORUŃ)

The French Spectre that Can(not) Be Tamed: The Great War in Short Narrative Forms

Sadkowski explores French short narrative forms by Henri-Frédéric Blanc, Gisèle Bienne and Cathie Barreau. Their works from the turn of the twentieth and twenty-first centuries - a period associated with post-memory - tackle the spectral presence of trauma related to the experience of World War I. These short works present the figure of the witness in the second degree not so much as a subject haunted by the spectre of World War I but rather as a subject that invokes those ghosts. These characters try - with various degrees of success - to tame those ghosts, to bring them alive and to include them in their own histories. The work of fiction becomes a substitute of verbalizing the trauma. It may come short of bringing about symbolic healing, but it seems to ease the process of coming to terms with the knowledge that the traces of the past will never disappear.

\section{Keywords}

World War I, spectre, trauma, narration, witness in the second degree

84 Zob. J. Derrida Widma Marksa, s. 13-14. 